\title{
Faktor-Faktor Risiko Feline Panleukopenia pada Kucing di Daerah Istimewa Yogyakarta
}

\section{Risk Factors of Feline Panleukopenia in Cats in Special Region of Yogyakarta}

\author{
Riyandini Putri ${ }^{1 *}$, Bambang Sumiarto ${ }^{2}$, Guntari Titik Mulyani ${ }^{3}$ \\ ${ }^{1}$ Fakultas Kedokteran Hewan, Universitas Gadjah Mada \\ ${ }^{2}$ Departemen Kesehatan Masyarakat Veteriner \\ ${ }^{3}$ Departemen Ilmu Penyakit Dalam \\ Fakultas Kedokteran Hewan Universitas Gadjah Mada, Jalan Fauna No. 2, Karangmalang, Yogyakarta 55281 \\ *Email: riyandini.putri@mail.ugm.ac.id
}

Naskah diterima: 21 Agustus 2019, direvisi: 19 Nopember 2019, disetujui: 3 Desember 2019

\begin{abstract}
Feline panleukopenia virus (FPV) infection in cats caused a disease called feline panleukopenia with high morbidity and mortality worldwide. This study was designed to investigate the risk factors of feline panleukopenia in Special Region of Yogyakarta. A retrospective case-control study used 35 cats in each of the case and control group. Case group is defined as cat tested positive with Anigen FPV Ag Test Kit (Bionote, South Korea). Control group is defined as healthy owned cat within the same neighbourhood of case group cat which matched by age and sex. The data assessment was included owner characteristics i.e. formal education, occupation, duration of having cat(s), monthly majntenance cost, and interaction time per day, also cat characteristics i.e. breed, neuter status, origin, husbandry, and vaccination status. Data was analysed using EpiInfo (chi-square and odds ratio) and manually calculated (estimated attributable fraction). Associated risk factors to feline panleukopenia incidents were unvaccinated cat, introduction of new cat(s), cat origins i.e pet shop or pet market, being a stray cat, domestic breed, and novice cat(s) owner (less than a year). It can be advised that owner's knowledge about vaccination and quarantine of new cat are the most important measures to prevent feline panleukopenia.
\end{abstract}

Key words: case-control study; cats; feline panleukopenia

\begin{abstract}
Abstrak
Feline panlaukopenia virus (FPV) pada kucing menyebabkan feline panleukopenia. Penyakit ini memiliki morbiditas dan mortalitas tinggi dengan penyebaran di seluruh dunia. Penelitian ini bertujuan untuk menyidik faktor-faktor risiko feline panleukoenia pada kucing di Daerah Istimewa Yogyakarta (DIY). Kajian kasus kontrol retrospektif digunakan dengan 35 kasus dan 35 kontrol. Kelompok kasus meliputi semua kucing penderita feline panleukopenia yang dinyatakan positif pada pengujian Anigen FPV Ag Test Kit (Bionote, Korea Selatan). Kelompok kontrol adalah kucing yang dipelihara oleh tetangga pemilik kucing kelompok kasus dengan umur dan jenis kelamin sebagai variabel matching. Faktor risiko yang diteliti meliputi karakteristik pemilik (pendidikan, pekerjaan, lama memelihara kucing, biaya pemeliharaan per bulan, dan waktu interaksi per hari) serta karakteristik kucing meliputi jenis kucing, status kebiri, asal kucing, manajemen pemeliharaan, serta status vaksinasi. Analisis data dilakukan dengan EpiInfo (chi-square dan odds ratio) dan perhitungan manual (estimated attributable fraction). Hasil penyidikan menunjukkan bahwa faktor risiko feline panleukopenia adalah kucing yang tidak divaksin, keberadaan kucing baru, asal kucing dari pasar hewan dan kucing liar, kucing lokal, dan memelihara kucing kurang dari satu tahun. Dari hasil penelitian dapat disarankan bahwa vaksinasi dan karantina kucing baru merupakan tindakan paling penting dalam pencegahan feline panleukopenia.
\end{abstract}

Kata kunci: studi kasus-kontrol; kucing; feline panleukopenia 


\section{Pendahuluan}

Kepemilikan kucing di Indonesia meningkat setiap tahunnya. Pemeliharaan kucing sebelumnya ditujukan untuk mengurangi populasi tikus, tetapi saat ini masyarakat memelihara kucing sebagai kegemaran atau hewan kesayangan. Oleh karena itu, masyarakat akan lebih memperhatikan kesehatan dari kucing peliharannya dan memeriksakan ke klinik atau rumah sakit hewan jika kucing terserang suatu penyakit. Feline panleukopenia adalah salah satu penyakit yang sering menginfeksi kucing.

Feline panleukopenia disebabkan oleh feline panleukopenia virus (FPV) yang merupakan anggota famili Parvoviridae. Gejala klinis bervariasi mulai dari infeksi subklinis hingga perakut yang ditandai dengan kematian secara tiba-tiba. Kucing yang terinfeksi mengalami kematian akibat komplikasi dari infeksi sekunder dari bakteri, sepsis, dehidrasi, dan disseminated intravasal coagulopathy (DIC). Tingkat morbiditas dan mortalitas cukup tinggi terutama pada kucing muda di bawah 12 minggu. Feline panleukopenia akut memiliki tingkat mortalitas $25-90 \%$ dan mencapai $100 \%$ pada infeksi perakut (Hartmann, 2017). Prevalensi FPV pada masingmasing daerah berbeda. Beberapa klinik hewan melaporkan banyak kasus feline panleukopenia, tetapi juga ada yang tidak melaporkan kasus meskipun metode diagnosa yang digunakan sama (Decaro et al., 2010; Truyen dan Parrish, 2013; Hartmann, 2017).

Kasus feline panleukopenia pertama kali dilaporkan pada tahun 1920-an oleh Verge dan Christoforoni (1928). Saat ini antibodi terhadap feline panleukopenia telah dilaporkan di beberapa negara, seperti Vietnam (Miyazawa et al., 1999), Thailand (Pirarat et al., 2002), Amerika Serikat (Lappin et al., 2002; DiGangi et al., 2011; Litster and Benjanirut, 2014), Korea Selatan (Kang et al., 2007; Shin et al., 2012; Kim et al., 2013), Jerman (Neuerer et al., 2008; Mende et al., 2014), Iran (Mosallanejad et al., 2009), Italia (Decaro et al., 2010), Hungaria (Demeter et al., 2010), Portugal (Duarte et al., 2012; Miranda et al., 2017), India (Parthiban et al., 2014; Mukhopadhyay et al., 2017; Raheena et al., 2017), Turki (Gur dan Avdatek, 2016), dan Mesir (Awad et al.,
2018). Infeksi feline panleukopenia pada kucing di Indonesia telah dibuktikan secara serologik dengan uji hemagglutinasi (HI) dan uji serum neutralisasi (SN) oleh Syafriati dan Sendow (2003). Titer antibodi positif berdasarkan uji HI yaitu sebanyak 79,17\% dan SN 76,54\% untuk wilayah DKI Jakarta dan Bogor.

Terapi kausatif untuk feline panleukopenia saat ini belum ada, sehingga pencegahan penyakit diutamakan untuk pengendalian penyakit. Program pencegahan penyakit yang baik memerlukan pengetahuan mengenai faktor risiko terjadinya penyakit. Penelitian mengenai faktor risiko kejadian feline panleukopenia di Indonesia belum banyak dilakukan. Penelitian ini bertujuan untuk mengetahui faktor-faktor risiko yang mempengaruhi kejadian feline panleukopenia serta asosiasi, kekuatan, dan efek antara faktor penyebab dengan kejadian feline panleukopenia pada kucing di Daerah Istimewa Yogyakarta (DIY) sehingga pencegahan penyakit dapat dilakukan sedini mungkin. Faktor-faktor yang akan dikaji pada kajian kasus-kontrol ini meliputi jenis kucing, status kebiri, asal kucing, manajemen pemeliharaan, serta status vaksinasi dengan variabel matching berupa jenis kelamin dan umur. Karakteristik responden meliputi pendidikan formal, pekerjaan, lama memelihara kucing, biaya pemeliharaan per bulan, dan waktu interaksi dengan kucing per hari.

\section{Materi dan Metode}

\section{Populasi Studi}

Besaran sampel pada kelompok kasus dan kelompok kontrol dengan rasio 1:1 dihitung menggunakan rumus Schlesselman (1982). Hasil sampel dalam setiap kelompok sebesar 16 diperoleh dari nilai $\psi=15,575$ (Bergmann et al., 2018) dan $\mathrm{p}_{0}=0,05$. Penelitian ini menggunakan 35 ekor kucing pada kelompok kasus dan 35 ekor kucing pada kelompok kontrol.

Kelompok kasus meliputi kucing penderita feline panleukopenia yang didiagnosis secara klinis dan dinyatakan positif dengan uji Anigen FPV Ag Test Kit (Bionote, Korea Selatan). Kasus yang digunakan adalah kasus yang tercatat dalam rekam medis pada bulan Oktober - Desember 2018 pada klinik hewan Kayu Manis dan Naroopet 
di DIY. Kucing pada kelompok kasus meliputi semua golongan umur dan jenis kelamin, berada di wilayah DIY, serta memiliki pemilik. Kelompok kontrol adalah kucing yang dipelihara oleh tetangga dari pemilik kucing pada kelompok kasus dalam satu RT dengan umur dan jenis kelamin disesuaikan dengan kelompok kasus. Kucing dikeluarkan dari kelompok kasus dan kontrol apabila kucing tidak memiliki pemilik dan tidak memiliki data historis seperti halnya pada kucing liar. Selain itu, apabila kucing pernah tidak pulang selama lebih dari satu minggu maka kucing tidak dipilih sebagai sampel. Penentuan faktor risiko dilakukan dengan wawancara pemilik kucing menggunakan kuisioner terstruktur. Observasi lingkungan sekitar rumah responden dilakukan untuk mencocokkan jawaban wawancara.

\section{Analisis Data}

Tabel $3 \times 2$ dan $4 \times 2$ ditransformasi untuk memperoleh variabel dummy dalam tabel $2 \times 2$ sehingga pengaruh dari setiap variabel dummy terhadap kejadian penyakit dapat diketahui. Analisis data dilakukan dengan menggunakan perangkat lunak EpiInfo untuk mengetahui nilai McNemar's test, Fisher's exact test, nilai probabilitas (p), odds ratio (OR), dan 95\% confidence interval (CI). Estimasi attributable fraction (AF) dihitung menggunakan rumus $\frac{O R-1}{O R}$ (Martin et al., 1987).

\section{Hasil dan Pembahasan}

Karakteristik demografi pemilik diteliti untuk memahami potensi hubungan antara faktor pemilik

Tabel 1. Analisis bivariat faktor pemilik kucing terhadap kejadian feline panleukopenia.

\begin{tabular}{|c|c|c|c|c|c|c|c|c|}
\hline No. & Variabel & & & ntrol & $\begin{array}{l}\text { Estimasi } \\
\text { OR }\end{array}$ & $\begin{array}{c}95 \% \\
\text { CI }\end{array}$ & $\begin{array}{l}\text { Estimasi } \\
\mathrm{AF}\end{array}$ & $\begin{array}{l}\text { Nilai } \\
\mathrm{p}\end{array}$ \\
\hline 1. & Pendidikan terakhir & & $\begin{array}{c}\text { Sekolah } \\
\text { Menengah } \\
\text { Atas (SMA) }\end{array}$ & $\begin{array}{l}\text { Perguruan } \\
\text { Tinggi (PT) }\end{array}$ & & \multirow{3}{*}{$0,44-4,41$} & \multirow{4}{*}{0,29} & \multirow{3}{*}{0,581} \\
\hline \multirow{9}{*}{2.} & \multirow[t]{2}{*}{ Kasus } & $\begin{array}{l}\text { Sekolah } \\
\text { Menengah Atas } \\
\text { (SMA) }\end{array}$ & 0 & 7 & 1,40 & & & \\
\hline & & $\begin{array}{l}\text { Perguruan } \\
\text { Tinggi (PT) }\end{array}$ & 5 & 23 & Ref. & & & \\
\hline & \multirow{2}{*}{\multicolumn{2}{|c|}{$\begin{array}{l}\text { Pekerjaan } \\
\text { Pegawai Negeri Sipil (PNS) }\end{array}$}} & & & & & & \\
\hline & & & Ya & Tidak & & & & \\
\hline & & Ya & 1 & 6 & 3,00 & $0,60-14,86$ & 0,67 & 0,180 \\
\hline & Kasus & Tidak & 2 & 26 & Ref. & & & \\
\hline & \multirow{3}{*}{ Kasus } & & Tidak & Ya & & & & \\
\hline & & Tidak & 2 & 10 & 3,33 & $0,92-12,11$ & 0,70 & 0,057 \\
\hline & & $\mathrm{Ya}$ & 3 & 20 & Ref. & & & \\
\hline & Pelajar/Mahasiswa & & Ya & Tidak & & \multirow{3}{*}{$0,58-42,80$} & \multirow{3}{*}{0,80} & \multirow{3}{*}{0,125} \\
\hline \multirow{4}{*}{3.} & \multirow[t]{2}{*}{ Kasus } & Ya & 0 & 5 & 5,00 & & & \\
\hline & & Tidak & 1 & 29 & Ref. & & & \\
\hline & \multicolumn{2}{|c|}{ Lama memelihara kucing } & $\leq 1$ tahun & $>1$ tahun & & \multirow{3}{*}{$1,15-10,63$} & \multirow{3}{*}{0,71} & \multirow{3}{*}{$0,019^{*}$} \\
\hline & \multirow[t]{2}{*}{ Kasus } & $\leq 1$ tahun & 2 & 14 & 3,50 & & & \\
\hline & & $>1$ tahun & 4 & 15 & Ref. & & & \\
\hline \multirow[t]{3}{*}{4.} & Biaya setiap bulan & & $\leq \operatorname{Rp} 500.000$ & $>\operatorname{Rp} 500.000$ & & \multirow{3}{*}{$0,51-5,98$} & \multirow{3}{*}{0,43} & \multirow{3}{*}{0,388} \\
\hline & Kasus & $\leq \operatorname{Rp} 500.000$ & 22 & 7 & 1,75 & & & \\
\hline & & $>\operatorname{Rp} 500.000$ & 4 & 2 & Ref. & & & \\
\hline \multirow[t]{3}{*}{5.} & Waktu interaksi harian & & $>30$ menit & $\leq 30$ menit & & \multirow{3}{*}{$0,50-12,36$} & \multirow{3}{*}{0,50} & \multirow{3}{*}{0,344} \\
\hline & Kasus & $>30$ menit & 24 & 6 & 2,00 & & & \\
\hline & & $\leq 30$ menit & 3 & 2 & Ref. & & & \\
\hline
\end{tabular}


dan manajemen pemeliharaan kucing terhadap kejadian penyakit. Faktor pemeliharaan kucing dan gaya hidup mungkin mempengaruhi risiko paparan agen infeksius, risiko trauma fisik, atau kecenderungan adanya masalah perilaku tertentu (Johnston et al., 2017).

Analisis faktor responden atau pemilik terhadap kejadian feline panleukopenia dapat dilihat pada Tabel 1. Lama pemeliharaan dihubungkan dengan pengalaman memelihara kucing. Waktu pemeliharaan kucing semakin lama maka pemilik memiliki pengetahuan lebih banyak mengenai perilaku kucing dan melakukan manajemen pemeliharaan yang baik. Kucing dengan pemilik yang memelihara kucing kurang dari satu tahun memiliki kemungkinan 3,50 kali lebih besar

Tabel 2. Analisis bivariat faktor risiko karakteristik kucing terhadap kejadian feline panleukopenia.

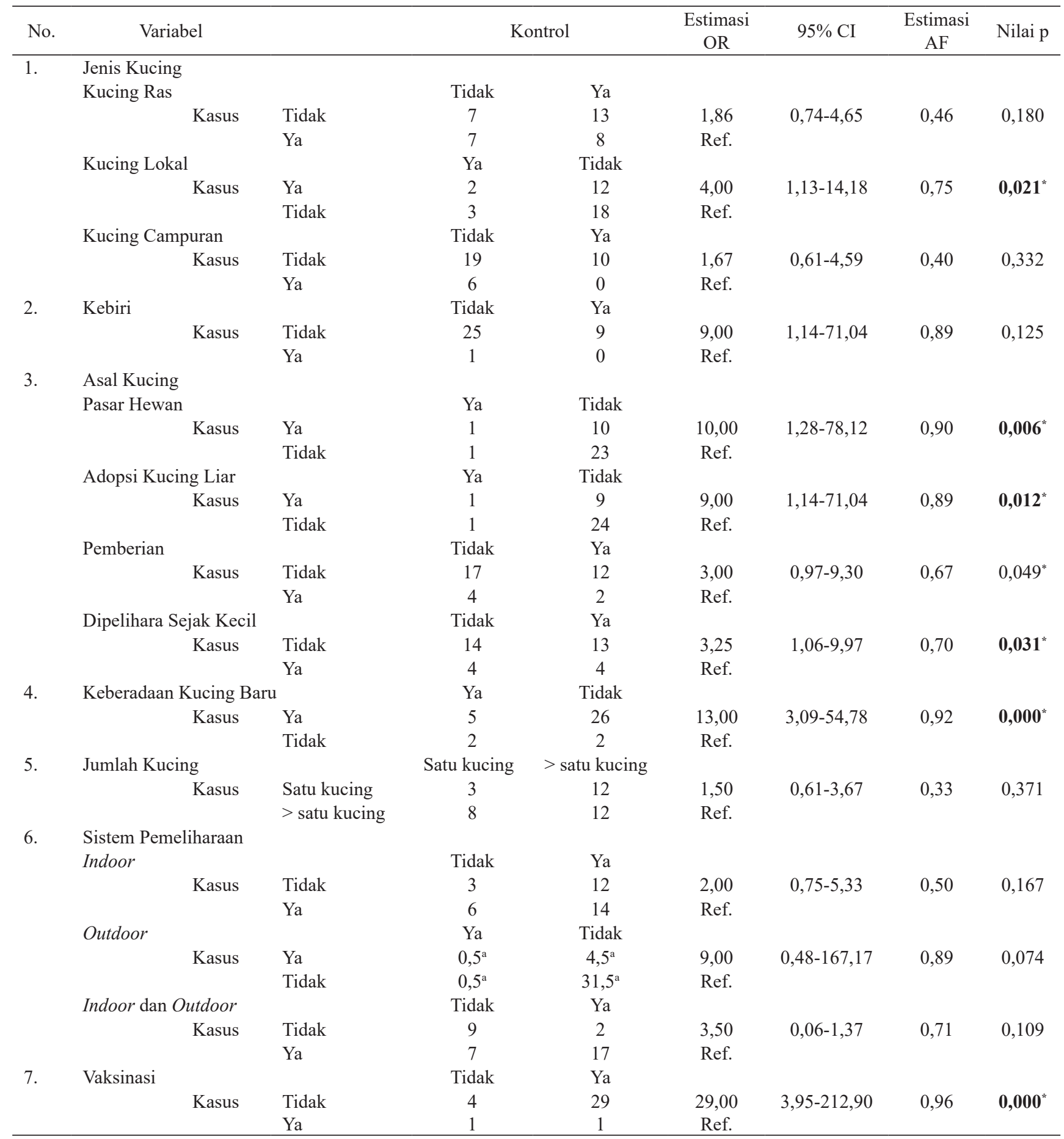

Keterangan: $\mathrm{p}$ : Probabilitas; ${ }^{*} \mathrm{p}<0,05$; OR : Odds ratio; CI : Confidence interval; AF : Attributable fraction; ${ }^{\mathrm{a}}$ : koreksi HaldaneAnscombe, Ref. : Nilai referensi atau pembanding. 
terjangkit feline panleukopenia dibandingkan kucing dengan pemilik yang telah memelihara kucing lebih dari satu tahun.

Faktor pemilik meliputi pendidikan, pekerjaan Pegawai Negeri Sipil (PNS), pegawai swasta, pelajar, biaya yang dikeluarkan dalam satu bulan untuk setiap kucing, dan waktu harian interaksi dengan kucing tidak memiliki asosiasi terhadap kejadian penyakit feline panleukopenia $(\mathrm{p}>0,05)$. Hasil penelitian Brady et al. (2012) menunjukkan bahwa pengaruh faktor sosio-ekonomi terhadap penyakit canine parvovirus di Australia berbeda dengan penelitian ini. Hasil penelitian tersebut menyebutkan bahwa kejadian penyakit lebih tinggi pada klaster dengan sosio-ekonomi tingkat bawah serta tingkat pekerjaan, penghasilan, dan pendidikan rendah. Pemilik hewan kesayangan yang berpendidikan lebih rendah berpeluang lebih tinggi untuk membuang atau mengeliminasi hewan mereka ke shelter. Hal ini berpengaruh besar pada overpopulasi hewan kesayangan (Ramon et al., 2010) yang berperan dalam penyebaran penyakit. Kucing dengan biaya perawatan lebih besar mengindikasikan bahwa manajemen pemeliharaan kucing tersebut lebih baik karena pemilik mengeluarkan uang lebih banyak untuk pakan, pasir, dan perawatan kesehatan meliputi sterilisasi atau kebiri, obat cacing untuk parasit intestinal profilaksis, dan vaksinasi (Ramon et al., 2010; Brady et al., 2012).

Analisis karakteristik kucing terhadap kejadian feline panleukopenia dapat dilihat pada Tabel 2. Kucing lokal memiliki asosiasi terhadap kejadian penyakit feline panleukopenia ( $\mathrm{p}=$ 0,021) dan mempunyai kemungkinan 4,00 kali lebih besar terjangkit feline panleukopenia dibandingkan kucing ras dan kucing campuran. Kasus feline panleukopenia dapat dieliminasi sekitar $75 \%$ pada kucing ras dan campuran. Manajemen pemeliharaan termasuk tindakan preventif pada kucing lokal biasanya tidak sebaik kucing ras atau kucing campuran sehingga kucing lokal lebih rentan terhadap penyakit.

Faktor kucing ras, kucing campuran, dan status kebiri $(p>0,05)$ tidak memiliki asosiasi terhadap kejadian penyakit feline panleukopenia. Hal ini sesuai dengan penelitian yang dilakukan oleh Mende et al. (2014) bahwa jenis kucing atau breed yang terbatas pada jenis maine coon dan domestic short hair $\left(\chi^{2}=1,75\right)$ serta status kebiri $\left(\chi^{2}=0,05\right)$ tidak memiliki asosiasi dengan kurangnya antibodi terhadap feline panleukopenia virus (FPV).

Asal kucing memiliki asosiasi dengan kejadian feline panleukopenia. Kucing yang berasal dari pasar hewan $(\mathrm{OR}=10,00)$ dan adopsi kucing liar $(\mathrm{OR}=9,00)$ memiliki kemungkinan lebih besar terjangkit feline panleukopenia. Kucing di pasar hewan dapat mengalami stres lingkungan akibat overcrowding, umur muda, dan belum divaksin sehingga kucing rentan terhadap infeksi FPV. Kim et al. (2013) mengungkapkan bahwa kucing liar menunjukkan tingkat positif FPV lebih tinggi dibandingkan kucing yang dipelihara dalam rumah karena kucing liar terpapar stres lingkungan lebih tinggi dan biasanya tidak divaksin.

Kucing yang dipelihara sejak kecil memiliki kemungkinan lebih kecil terjangkit feline panleukopenia. Kucing yang dipelihara sejak kecil bersama dengan induknya biasanya memiliki antibodi maternal yang cukup. Bila induk kucing sudah divaksin, maka kucing tersebut akan memiliki kekebalan terhadap infeksi FPV.

Penelitian ini menunjukkan bahwa keberadaan kucing baru memiliki asosiasi terhadap kejadian penyakit feline panleukopenia ( $\mathrm{p}=$ $0,000)$. Populasi dengan kucing baru mempunyai kemungkinan 13,00 kali lebih besar terjangkit feline panleukopenia dibandingkan populasi tanpa keberadaan kucing baru. Kasus feline panleukopenia dapat dieliminasi sekitar 92\% pada populasi tanpa kucing baru. Menurut Möstl et al. (2013), karantina pada kucing yang masuk ke dalam cat shelters memerlukan waktu minimal selama 3 minggu hingga vaksin mulai bekerja. Kucing yang baru masuk dalam cat shelter harus diperiksa oleh dokter hewan kemudian diberi obat cacing dan vaksinasi secepatnya. Hal-hal tersebut di atas dapat dilakukan oleh pemilik untuk mencegah penularan feline panleukopenia atau penyakit infeksius lainnya pada kucing baru.

Kolom tabel sistem pemeliharaan kucing outdoor pada Tabel 2 bernilai 0 sehingga HaldaneAnscombe correction diterapkan (Ruxton and Neuha, 2013). Jumlah kucing yang dipelihara dan sistem pemeliharaan indoor, outdoor, maupun campuran tidak memiliki asosiasi dengan kejadian feline panleukopenia $(\mathrm{p}>0,05)$. Hal ini sesuai dengan hasil penelitian Blanco et al. (2009). 
Vaksinasi memiliki asosiasi terhadap kejadian penyakit feline panleukopenia $(\mathrm{P}=0,000)$. Kucing yang belum divaksin mempunyai kemungkinan 29,00 kali lebih besar terjangkit feline panleukopenia dibandingkan kucing yang telah divaksin. Kasus feline panleukopenia dapat dieliminasi sekitar $96 \%$ pada kucing yang telah divaksin. Hal ini sesuai dengan penelitian yang dilakukan oleh Mende et al. (2014) bahwa kucing tanpa vaksinasi $\left(\chi^{2}=23,51\right)$ memiliki asosiasi dengan kurangnya antibodi terhadap FPV sehingga kucing berisiko terinfeksi feline panleukopenia.

\section{Kesimpulan dan Saran}

Kucing yang tidak divaksin $(\mathrm{OR}=29,00$; 95\% CI $=3,95-212,90)$, keberadaan kucing baru $(\mathrm{OR}=13,00 ; 95 \% \mathrm{CI}=3,09-54,78)$, asal kucing dari pasar hewan $(\mathrm{OR}=10,00 ; 95 \% \mathrm{CI}=1,28$ $78,12)$ dan adopsi kucing liar $(\mathrm{OR}=9,00 ; 95 \%$ $\mathrm{CI}=1,14-71,04)$, jenis kucing lokal $(\mathrm{OR}=4,00$; 95\% $\mathrm{CI}=1,13-14,18)$, dan lama memelihara kucing kurang dari satu tahun $(\mathrm{OR}=3,50 ; 95 \%$ $\mathrm{CI}=1,15-10,63)$ merupakan faktor risiko kejadian feline panleukopenia pada kucing.

Berdasarkan hasil dari penelitian ini, vaksinasi dan karantina bagi hewan baru merupakan tindakan yang paling disarankan guna mencegah feline panleukopenia pada kucing. Kasus feline panleukopenia dapat dieliminasi sekitar $92 \%$ pada populasi tanpa kucing baru dan sekitar 96\% pada kucing yang telah divaksin.

\section{Ucapan Terima Kasih}

Ucapan terima kasih disampaikan kepada segenap staf dan pegawai Klinik Hewan Kayu Manis dan Naroopet yang telah membantu dalam pengumpulan data pada kelompok kasus.

\section{Daftar Pustaka}

Awad, R. A., Khalil, W. K. B., \& Attallah, A. G. (2018). Epidemiology and diagnosis of feline panleukopenia virus in Egypt: Clinical and molecular diagnosis in cats. Veterinary World, 11(5), 578-584.

Bergmann, M., Schwertler, S., Reese, S., Speck, S., Truyen, U., \& Hartmann, K. (2018). Antibody response to feline panleukopenia virus vaccination in healthy adult cats. Journal of Feline Medicine and Surgery, 20(12), 1087-1093.

Blanco, K., Prendas, J., Cortes, R., Jimenez, C., \& Dolz, G. (2009). Seroprevalence of Viral Infections in Domestic Cats in Costa Rica. Journal of Veterinary Medical Science, 71(5), 661-663.

Brady, S., Norris, J. M., Kelman, M., \& Ward, M. P. (2012). Canine parvovirus in Australia: The role of socio-economic factors in disease clusters. The Veterinary Journal, 193(2), 522-528.

Csiza, C. K., Scott, F. W., De Lahunta, A., \& Gillespie, J.H.(1971). Pathogenesis of feline panleukopenia virus in susceptible newborn kittens I. Clinical signs, hematology, serology, and virology. Infection and Immunity, 3(6), 833-7.

Decaro, N., Buonavoglia, D., Desario, C., Amorisco, F., Colaianni, M. L., Parisi, A., Terio, V., Elia, G., Lucente, M. S., Cavalli, A., Martella, V., \& Buonavoglia, C. (2010). Characterisation of canine parvovirus strains isolated from cats with feline panleukopenia. Research in Veterinary Science, 89(2), 275-278.

Demeter, Z., Palade, E. A., \& Rusvai, M. (2010). Feline Panleukopenia Virus Infection in Various Species From Hungary. Lucrari Stiintifice Medicina Veterinara, 43(1), 7381.

DiGangi, B. A., Gray, L. K., Levy, J. K., Dubovi, E. J., \& Tucker, S. J. (2011). Detection of protective antibody titers against feline panleukopenia virus, feline herpesvirus-1, and feline calicivirus in shelter cats using a point-of-care ELISA. Journal of Feline Medicine and Surgery, 13(12), 912-918.

Duarte, A., Fernandes, M., Santos, N., \& Tavares, L. (2012). Virological Survey in freeranging wildcats (Felis silvestris) and feral domestic cats in Portugal. Veterinary Microbiology, 158(3-4), 400-404.

Gur, S., \& Avdatek, K. (2016). A serological investigation for feline panleukopenia 
virus in Cats in Afyonkarahisar. Kocatepe Veterinary Journal, 9(3), 165-170.

Hartmann, K. (2017). Feline Panleukopenia Update on Prevention. The Thai Journal of Veterinary Medicine, 47, S101-S104.

Johnston, L., Szczepanski, J., \& Mcdonagh, P. (2017). Demographics, lifestyle and veterinary care of cats in Australia and New Zealand. Journal of Feline Medicine and Surgery, 19(12), 1-7.

Kang, S. C., Kang, K. Il, Jean, Y. H., \& Kim, J. H. (2007). Feline Panleukopenia Virus Infection in Imported Cats. Korean Journal of Veterinary Research, 47(4), 437-441.

Kim, S. G., Lee, K. I., Kim, H. J., \& Park, H. M. (2013). Prevalence of feline panleukopenia virus in stray and household cats in Seoul, Korea. Journal of Veterinary Clinics, 30(5), 333-338.

Lappin, M. R., Andrews, J., Simpson, D., \& Jensen, W. A. (2002). Use of serologic tests to predict resistance to feline herpesvirus 1 , feline calicivirus, and feline parvovirus infection in cats. Journal of the American Veterinary Medical Association, 220(1), 38-42.

Litster, A., \& Benjanirut, C. (2014). Case series of feline panleukopenia virus in an animal shelter. Journal of Feline Medicine and Surgery, 16(4), 346-353.

Martin, S. W., Meek, A. H., \& Willeberg, P. (1987). Veterinary Epidemiology; Principles and Methods (First ed). Ames: Iowa State University Press.

Mende, K., Stuetzer, B., Sauter-Louis, C., Homeier, T., Truyen, U., \& Hartmann, K. (2014). Prevalence of antibodies against feline panleukopenia virus in client-owned cats in Southern Germany. Veterinary Journal, 199(3), 419-423.

Miranda, C., Vieira, M. J., Silva, E., Carvalheira, J., Parrish, C. R., \& Thompson, G. (2017). Genetic Analysis of Feline Panleukopenia Virus Full-length VP2 Gene in Domestic Cats Between 2006-2008 and 2012-2014, Portugal. Transboundary and Emerging Diseases, 64(4), 1178-1183.
Miyazawa, T., Ikeda, Y., Nakamura, K., Naito, R., Mochizuki, M., Tohya, Y., Vu, D., Mikami, T., \& Takahashi, E. (1999). Isolation of Feline Parvovirus from Peripheral Blood Mononuclear Cells of Cats in Northern Vietnam. Microbiology and Immunology, 43(6), 609-612.

Mosallanejad, B., Avizeh, R., \& Ghorbanpoor Najafabadi, M. (2009). Antigenic detection of feline panleukopenia virus (FPV) in diarrhoeic companion cats in Ahvaz area. Iranian Journal of Veterinary Research, 10(3), 289-293.

Möstl, K., Egberink, H., Addie, D., Frymus, T., Boucraut-Baralon, C., Truyen, U., Hartmann, K., Lutz, H., Gruffydd-Jones, T., Radford, A. D., Lloret, A., Pennisi, M. G., Hosie, M. J., Marsilio, F., Thiry, E., Belák, S., \& Horzinek, M. C. (2013). Prevention of infectious diseases in cat shelters: ABCD guidelines. Journal of Feline Medicine and Surgery, 15(7), 546-554.

Mukhopadhyay, H. K., Nookala, M., Thangamani, N. R. K., Sivaprakasam, A., Antony, P. X., Thanislass, J., Srinivas, M. V., \& Pillai, R. M. (2017). Molecular characterisation of parvoviruses from domestic cats reveals emergence of newer variants in India. Journal of Feline Medicine and Surgery, 19(8), 846-852.

Neuerer, F. F., Horlacher, K., Truyen, U., \& Hartmann, K. (2008). Comparison of different in-house test systems to detect parvovirus in faeces of cats. Journal of Feline Medicine and Surgery, 10(3), 247251.

Parthiban,M.,Aarthi,K.S.,Balagangatharathilagar, M., \& Kumanan, K. (2014). Evidence of feline panleukopenia infection in cats in India. Virus Disease, 25(4), 497-499.

Pirarat, N., Kaewamatawong, T., \& Techangamsuwan, S. (2002). A retrospective immunohistochemistry study on feline panleukopenia virus, induced enteritis, in cats. Thai Journal of Veterinary Medicine, 32(4), 71-78. 
Raheena, K. P., Priya, P. M., Mani, B. K., Mini, M., \& Pillai, U. N. (2017). Comparison of different diagnostic test to detect feline panleukopenia virus among cats in Kerala, India. Indian Journal of Animal Research, 51(2), 347-349.

Ramon, M. E., Slater, M. R., \& Ward, M. P. (2010). Companion animal knowledge, attachment and pet cat care and their associations with household demographics for residents of a rural Texas town. Preventive Veterinary Medicine, 94, 251-263.

Ruxton, G. D., \& Neuha, M. (2013). Review of alternative approaches to calculation of a confidence interval for the odds ratio of a 2 x 2 contingency table. Methods in Ecology and Evolution, 4, 9-13.

Schlesselman, J. J. (1982). Case Control Study: Design, Conduct, Analysis. New York: Oxford University.
Shin,A., Lee, M., Kim, S., \& Kang, S. H.(2012). Online capillary electrophoresis for enhanced detection sensitivity of feline panleukopenia virus. Journal of Chromatography $B$ : Analytical Technologies in the Biomedical and Life Sciences, 909, 22-25.

Syafriati, T., \& Sendow, I. (2003). Keberadaan Penyakit Feline Panleukopenia pada Kucing di Indonesia. Seminar Nasional Teknologi Peternakan dan Veteriner, Bogor: 29-30 September 2003. Hal. 477-480.

Truyen, U., \& Parrish, C. R. (2013). Feline panleukopenia virus: Its interesting evolution and current problems in immunoprophylaxis against a serious pathogen. Veterinary Microbiology, 165, 29-32. 